\title{
Family Unity in Immigration and Refugee Matters: United States and European Approaches
}

\section{CYNTHIA S. ANDERFUHREN-WAYNE*}

\section{Introduction}

As an institution deriving from the most fundamental of religious teachings, the family unit contains strong moral underpinnings which have long served to substantiate its importance within a legal framework:

In virtually all societics, families are considered the cornerstone of socicty, for security, economic and, of course, procreation reasons ... The importance of the family as the basic unit of society ... (is) ... embedded in most cultures, in traditions, prescriptions, laws and religious teaching.'

It is thus not surprising that international instruments such as the Universal Declaration of Human Rights speak of the family as 'the natural and fundamental group unit of society ... entitled to protection by society and the State' (Article 16.3), and that a host of other legal instruments, both universal and regional, similarly uphold the sanctity of the family and its right to protection. An obligation to protect families is also found in, among other treaties, the International Covenant on Civil and Political Rights (Article 23 (1)), the American Convention on Human Rights (Article 17(1)), the African Charter on Human and People's Rights (Article 18(1)), the European Social Charter (Article 16) and the International

* US attorney at law (Juris Doctor) and legal research assistant at Seminar für öffendiches Recht (Faculty of Public Law), University of Berne, Switzerland. My sincere thanks to Professor Dr. Walter Kälin for his guidance in the preparation of this article.

1 Peter van Kriegen, The Family and Intemational Law: The Principle of Family Unity and Family Reunification, 1, UNHCR Stockholm, May 1993 (distributed at Seminar on Family Reunification for Refugees, organized by the Danish Refugee Council in Helsingor, Denmark, 15-17 May 1993.) 
Covenant on Economic, Social and Cultural Rights (Article 10). ${ }^{2}$ Although the European Convention on Human Rights ${ }^{3}$ does not specifically mention 'protection,' the obligation to protect families is succinct: Article 8 of this convention containing, among other things, a right of respect for family life has been the basis of much case law development on the obligation of protection. ${ }^{4}$

On a domestic level, the constitutions of at least 50 countries provide for family protection. ${ }^{5}$ In countries where no specific constitutional provision exists, protection is often present. Although the US Constitution has no express provision on family rights, the Supreme Court has stated that '(i)r any freedom not specifically mentioned in the Bill of Rights enjoys a "preferred position" in the law, it is most certainly the family. "In its case law the Court has noted, "(O)ur decisions establish that the Constitution protects the sanctity of the family precisely because the institution of the family is deeply rooted in this nation's history and tradition." That the family unit comprises an integral part of the US constitutional system has also been stressed by scholars: '(O)ur political system is superimposed on and presupposes a social system of family units, not just of isolated individuals. No assumption more deeply underlies our society ....'

In light of the foregoing, one might expect that families 'in need' could count on legal protection on both a domestic and international level. However, one does not have to look far to realize that this proliferation of honour and protection is rather transparent in practice, particularly when viewed in the context of families which, for varying reasons, have been separated by flight or migration and are now seeking to reunite. For one thing, there is no unified approach regarding a right to family unity or what family protection encompasses. Furthermore, despite recognition of the family unit, its significance and its need for protection, obstacles to family reunification are deep-rooted and manifold.

This article focuses on the current situation regarding the right to

\footnotetext{
${ }^{2}$ Cvetic, G., 'Immigration Cases in Strasbourg. 'The Right to Family Life under Article 8 of the European Convention', 36 ICLQ647, 653 (1987). For further discussion, see Plender, R., Intemational Migration Law, (2nd rev. ed., 1988), 365-72. The obligation of protection has been recognized as a 'positive obligation', requiring States to take affrmative action to protect families where necessary. See further below.

3 European Convention for the Protection of Human Rights and Fundamental Freedoms of 4 November 1950, 213 UNTS 221 (1950), in force 3 Sept. 1953; ratified by 30 States on 1 Jan. 1995 (hereinafter European Convention).

'The European Court of Justice 'regularly' requires members of the European Community to comply with this provision. Storey, H., "The Right to Family Life and Immigration Case Law at Strasbourg', 39 ICLQ 328, 344 (1990).

${ }^{3}$ Plender, above note 2 , at $366-7$.

6 Moore a Cleveland, 431 US 494, 545 (1977)

7 Moore, 431 US at 540.

"Heymann \& Barzelay, 'The Forest and the Trees: Roe v. Wade and its Critics', 53 B.U.L. Rea $765,772-3$ (1973).
} 
family unity in the United States and Europe; it provides a general overview while delineating some of the more salient problems that have arisen in connection with family rights and immigration law. The first part offers a general analysis of the right to family unity as a right of protection, and considers the sources of this right. This is followed by a look at how the European Court of Human Rights and the Commission have dealt with family unity and by further consideration and comparison of family unity under US law. Although the European Court and Commission are not the only judicial bodies dealing with family cases in Europe, they have considered many related aspects and issues; their analysis, especially in connection with article 8 of the European Convention on Human Rights, thus provides a good starting point for considering the European approach to this subject. A comparative study is called for precisely because of the effects which newly implemented and more stringent immigration regulations in both Europe and the US are having on the family. Given the growth of immigration problems, resulting particularly from increasingly restrictive policies and the tightening of immigration quotas, family reunification is becoming increasingly difficult; the need for new ideas and approaches is thus more and more compelling. The article concludes with some proposals for solutions. More importantly, however, it attempts to access and organize problems in a critical sense, so as to clear away inconsistencies and provide a new perspective on where solutions are most urgently needed.

\subsection{The right to family unity in general: 'unity' and 'reunification' as aspects of protection}

Among the various aspects of the right to family unity, its acceptance as a right to protection of the family as a unit is fundamental. This manner of characterizing the right is found not only on a domestic but also on an international level. ${ }^{9}$ Beginning with the provisions of the Universal Declaration on Human Rights, most international human rights documents recognize a right of family unity. Family unity has been further defined as 'a right to recognition of a legal relationship between family members'. ${ }^{10}$ The right of unity is often distinguished from the right to reunification, which extends protection more specifically to families which have been separated and wish to reunite." Few international human rights instruments specifically designate a right of family reunification or otherwise elaborate on how the right to be treated as a unit should be implemented in cases of separated families. Among these, the Final Act

\footnotetext{
9 As one author notes, ' $(t)$ he principle of the unity of the family is firmly established in international law': Perruchoud, R., 'Family Reunification', 27 Int. Mig. 510 (1989).

${ }^{10}$ van Dijk, P. and van Hoof, G.J.H., Theory and Practice of the European Convention on Human rights, (2nd ed., 1990).

"See, for example, Perruchoud, above note 9, at 511 .
} 
of the Helsinki Conference directly addresses the problems occurring when family members reside in two different States; however, its provisions are principally concerned with migrants and emigration, as opposed to immigration. $^{12}$

Despite the lack of an express right of reunification, Plender notes that, at least among industrialized States, there is a policy of allowing the admission of persons who have been separated from their families ('where reasonable'): States, he notes, are under a 'certain political or moral predisposition ... to conduct their immigration policies so as to avoid unnecessary disruption to family life'. ${ }^{13}$ With respect to international instruments, he remarks that although ' $(t)$ aken together (they) do not amount to evidence of a right to family reunification in general international law, ... (they do) ... establish the widespread acceptance that States should facilitate admission to their territories of members of families of citizens or residents, at least when it would be unreasonable to expect the family to be reunited elsewhere'. ${ }^{4}$

Also indicative of a policy of reunification are various resolutions stressing the importance of reunification in connection with the principle of 'unity'. In 1981, the UNHCR Executive Committee concluded, with regard to family reunification and refugees, as follows:

In the application of the principle of the unity of the family and for obvious humanitarian reasons, every effort should be made to ensure the reunification of scparated refugec familics...

It is hoped that countrics of asylum will apply libcral critcria in identifying those family members who can bc admitted with a vicw to promoting a comprehensive rcunification of the family. ${ }^{15}$

Similarly, with regard to refugees and persons otherwise forced to leave their homelands, the Conclusions of the Thirteenth Round Table of the Institute of Humanitarian Law have stressed reunification in connection with unity:

The humanitarian principle of family reunification is firmly established in international practice ...

This principle is closely linked to the right of unity of the family which recognizes that the family is the natural and fundamental group unit of society and is entitled to protection by society and the State ...

... there exist different situations where families need to be reunited, and

\footnotetext{
12 Plender, above note 2, at 365 . For additional instruments mentioning reunification, see Perruchoud, above note 9 , at $510-11$.

13 Plender, above note 2 , at $374-5$.

14 Ibid. at 366 .

is Conclusion No. 24 (XXXII) Family Reunification, UNHCR Executive Committee, 32nd Session (1981), 1, 5.
} 
solutions must be reached in accordance with relevant international law and the requirements of the particular situation. ${ }^{16}$

The emphasis placed upon the role of reunification in connection with unity, despite the lack of an express right of reunification, illustrates the first wrinkle in this area of the law: On the one hand, family reunification calls for the movement of persons from one State to another. On the other hand, outside of specific bilateral or multilateral treaties, there is no right to immigrate and no general duty on the part of States to allow persons to enter their territories. ${ }^{17}$ Although, practically speaking, family reunification 'should be considered as a means of implementing the principle of family unity ..., ${ }^{18}$ under general international law it is merely a policy the force of which is vague and undefined - in effect, a right of unity without a clear means of executing it.

Recently, the importance of reunification rights and the need for more specific international provisions regarding them have been increasingly recognized. For example, it has been proposed that the UN adopt a specific declaration on the topic, and current literature has suggested that reunification is closely related to the right to leave and return, ${ }^{19}$ although it is clear that a right to leave one country does not automatically lead to a right to enter another.

The 1990 Convention on the Rights of the Child, in two consecutive articles, stresses not only unity but also reunification:

States Parties shall ensure that a child shall not be separated from his or her parents against their will, except when competent authorities subject to judicial review determinc, in accordance with applicable law and procedures, that such separation is necessary for the best interests of the child ...

In accordance with the obligation ... under article 9, paragraph 1 [above], applications ... to enter or leave a State Party for the purpose of family reunification shall be dealt with by States Partics in a positive, humanc and cxpeditious manner ... ${ }^{20}$

States nevertheless enjoy extensive discretion here, and increased support for reunification in law must be considered together with the fact that, ultimately, the decision as to whether or not to admit a family member

\footnotetext{
${ }^{16}$ Conclusions on Family Reunification, extract from Intemational Review of the Red Cross, Nov.-Dec., 1988. (formulated at the Thirteenth Round Table of the International Institute for Humanitarian Law, San Remo, 6-10 Sept. 1988), Conclusions 1, 2, 3.

17 Perruchoud, above note 9, at 511 .

18 Ibid.

19 Mubanga-Chipoya, C.L.C., 'The Right of Everyone to Leave any Country, Including his Own and to Return to his Country. Analysis of the current trends and developments regarding the right to leave any country including one's own, and to return to one's own country, and some other rights or considerations arising therefrom', UN doc. E/CN.4/Sub.2/1988/35, 20 Jun. 1988, 106.

${ }^{20}$ Arts. 9, 10, 1989 Convention on the Rights of the Child, adopted by UNGA res. 44/25, UN GAOR, 44th Sess., Supp. No. 49 at 166: UN doc. A/44/49 (1990); reprinted in 29 ILM 1448 (1989). In force 2 Sept. 1990 and ratified by 168 States at 1 Jan. 1995.
} 
is subject to competing interests within individual States, and that there is no uniform practice.

\subsection{European and US approaches to 'unity' and 'reunification'}

Both the European Court of Human Rights and the Commission discuss family unity and reunification within the framework of States' rights or obligations with regard to the admission and/or deportation of immigrants; their decisions are based mostly on article 8 of the European Convention on Human Rights. ${ }^{21}$ In all cases dealing with the issue of separated families and their rights to reunite or to remain together (in the face of deportation), the Court and the Commission have reiterated the general principle that there is no right to immigrate to another country simply because one has close family members there. On the other hand, the obligation to respect and/or protect families proscribes unreasonable or arbitrary interference with family life. ${ }^{22}$ Moreover, to a certain extent, States party to the European Convention give up the right to exclude whoever they want from their borders; ${ }^{23}$ and they may have a positive obligation to take some affirmative action to ensure this protection. ${ }^{24}$ Thus, depending upon varying circumstances, explored below, the exclusion of a person from a country where close family members reside may be impermissible.

Family reunification is stressed more frequently in the United States, where there is a tendency in immigration cases to focus on whether a person should be allowed to enter the country or be excluded. Reunification is a dominant feature of current arrangements for permanent immigration into the United States. For example, there is no official limit on the immigration of immediate relatives of US citizens, and under the preference system regulating the admission of immigrants, family sponsored immigration is given top priority.

US immigration legislation, set forth in the Immigration Act of 1990 (or ' $1990 \mathrm{Act}^{\text {', }}$,5 adding to and amending the Immigration and Nationality Act or ' INA $^{26}$ ) is rife with expressions of legislative concern for family

21 European Convention, above note 3.

22 The Commission has stated that '(c)xpulsion of or a refusal to admit a person to a State's territory resulting in an arbitrary separation of family members is a violation of Article $8^{\prime} . X_{a}$ Sweden, App. No. 434/50, II Y.B. Eur. Conn on H.R. 354 (1959).

${ }^{23}$ Abdulaziz and Balkandali a United Kingdom 94 Eur.C..H.R. (ser. A) (1985) 50, (hereinafter, Abdulaziz); This was even earlier adthered to by the Commission; see $X$ a Sweden, above note 22, at 354; $X$ a Austia and Yugoslavia, App. No. 2142/64, VII Y.B. Eur. Conn on H.R. 314 (1964); X a Germany, App. No. 6315/73, XVII Y.B. Eur. Conn on H.R. 480 (1974).

${ }_{24}$ See Markx Case, 31 Eur.C.H.R. (ser. A) (1979). Marckr is frequently cited in subsequent cases for establishing the positive obligation principle.

${ }^{25}$ Immigration Act of 1990 (1990 Act), Pub. L. No.101-649, Sec. 408(a), 104 Stat. 4978 (adding or amending many sections of the INA) (signed by the President on 29 Nov. 1990).

${ }^{26}$ Immigration and Nationality Act of 1952 (INA), Pub. L No. 82-414, 66 Stat. 163 (McCarranWalter Act; codified as amended at 8 USC Secs. 1101-1524). 
protection and reunification. Referring to the legislative history of a specific INA provision granting a special preference status, the US Supreme Court noted that it 'establishes that Congressional concern was directed "at the problem of keeping families of United States citizens and immigrants united". ${ }^{27}$ Other references to the Act have spoken of its 'humane purpose ... to reunite families ${ }^{\prime 28}$ and have characterized family reunification as 'one of the foremost polic(ies) underlying the granting of preference visas under the US immigration laws' ${ }^{29}$ With regard to US Supreme Court decisions protecting families from government intrusion, one author maintains that, at least with respect to parent-child and spousal relationships, the decisions provide a basis for recognizing a right to family unification. ${ }^{30} \mathrm{He}$ further notes that,

(i)deally, the courts in ... (the US) ... should recognize and enforce a constitutional right to family unification based on the premise that each person admitted as a permanent resident possesses a basic human right to live a normal family life."

Notwithstanding the above, family reunification remains a problem for a large number of persons wishing to immigrate to the United States. Spouses and children of permanent resident aliens (hcreinafter, PRAs) are subject to unduly long delays before consideration for entry which, in effect, violates their substantive due process rights to 'lead normal family lives'. ${ }^{32}$ There is also a difference in treatment on the basis of national origin because of numerical ceilings placed on immigration from different countries. Hence, a right to reunification for PRAs may vary, depending on the national origin of a spouse or minor child, a procedure which treads on notions of 'fundamental fairness' and 'equal protection'."

Underlying the conflict between the rhetorical support given to families and family reunification in the US and the practice which keeps many families apart is the plenary power doctrine, a doctrine rooted in sovereignty that gives the legislative and executive branches of government

\footnotetext{
${ }^{27}$ Fiallo a Bell 430 US 787, 795, n.6 (1977) quoting from H.R. Rep. No. 1199, 85th Cong., Ist Sess., 7 (1957), U.S. Code Cong. \& Admin. News, 1957, 2016, 2020.

${ }^{23}$ Kaliski u District Director, 620 F.2d 214, 217 (9th Cir., 1980).

*o Delgado a LNS, 473 F.Supp. 1343, 1348 (S.D.N.Y. 1979), quoting Lau u Kilg, 563 F.2d 543 (2nd Cir., 1977).

3) Guendelsberger, J., 'Implementing Fanily Unification Rights in American Immigration Law: Proposed Amendments', 25 San Diego Law Review 253, 266 (1988).

Ibid., at 276.

32 Ibid., at 270. 'Substantive due process', according to Black' Law Dictionary, is basically a 'protection from arbitrary or unreasonable action' as opposed to 'procedural due process', which consists of 'those safeguards to one's liberty and property mandated by the 14th Amend., US Constitution ...' Black's Law Dictionary (5th ed., 1983), 745, 628. As shown below, the distinction between substance and procedure is difficult and has been criticized as arbitrary in practice, particularly in connection with immigration matters. See Motomura, H., 'The Curious Evolution of Immigration Law: Procedural Surrogates for Substantive Constitutional Rights', 92 Columbia Law Reriaw 1625, $1628 f$ (1992).

"Guendelsberger, above note 30 , at 270 .
} 
broad and exclusive authority to regulate immigration matters. The relationship between the plenary power and sovereignty doctrines is clear from the comments of Justice Field in a Supreme Court case, Chae Chan Ping $v$. United States, ${ }^{34}$ decided close to the turn of the century:

The power to exclude aliens is an incident of every sovereign nation ... If it could not exclude aliens, it would be to that extent subject to the control of another power. A nation must be able to defend itself against vast hordes of people crowding in upon us. ${ }^{35}$

Although the plenary power doctrine does not give Congress unlimited power to regulate aliens, it can result in their exclusion under conditions which might otherwise be unconstitutional. ${ }^{36}$ Thus, as with the case of deference to State sovereignty in the Strasbourg cases, family rights in US immigration matters are limited by a doctrine pursuant to which the judicial branches defer in applying constitutional standards. A consideration of the right to family unity in light of the plenary power doctrine is rife with contradictions, as 'the issue of family rights in the context of immigration law mixes areas in which the Court has been most active on the one hand and most deferential on the other in its exercise of judicial review legislation'. ${ }^{37}$

Hence, under both US and European laws the right to family unity is a limited one. It is not only the doctrines of plenary power and State sovereignty which, in effect, circumscribe the right, but also the contradictions underlying these notions: That is, on the one hand, there is an emphasis placed upon the value and importance of families and family rights, including the right of reunification; on the other hand, there is a practice of limiting these rights in an effort to preserve State autonomy. The ensuing discussion will further examine European and US practices in connection with the European Convention and the US Constitution, respectively, and further elucidate the extent to which this contradiction is carried out.

\section{Article 8 of the European Convention on Human} Rights

A considerable body of case law regarding the right to family unity in immigration matters has evolved from Strasbourg. Pursuant to article 8 ECHR, family rights belong to a group of rights which fall within a 'right to privacy sphere', including, among others, rights of homosexuals,

\footnotetext{
34 Chae Chan Ping a United States, 130 US 581 (1889).

35 Ibid, at 606 .

36 For further discussion of the plenary power doctrine, see below.

37 Guendelsberger, above note 30 , at 262-3.
} 
pregnant woman and children. ${ }^{38}$ The family is granted a 'right of respect' and a 'right to freedom from interference by a public authority', which is then circumscribed in paragraph 2 as follows:

except such as is in accordance with the law and is necessary in a democratic society in the interests of national security, public safety or the economic wellbeing of the country, for prevention of disorder or crime, for the protection of public health or morals, or for the protection of rights and freedoms of others. ${ }^{39}$

Article 12 of the Convention, providing for the right to marry and have a family, as well as article 5 of Protocol No. 7 on spousal equality, are two further provisions relevant to family life. Article 14, prohibiting sexual and other forms of discrimination, has also been relied upon together with article $8 .^{40}$ This paper focuses on the family life provisions in article 8 , although article 12 plays an important role with regard to its specific rights, or where 'family life' cannot be proven. However, particularly in immigration matters, article 8 is more commonly invoked because it offers a wider range of protection. ${ }^{41}$

The bulk of the relevant case law dealing with family life in immigration cases has been decided by the European Commission. ${ }^{42}$ Two important decisions by the Court - Abdulaziz in $1985^{43}$ and Berrehab in $1988^{44}$ have, for the most part, followed the direction of the Commission with some small, albeit important, changes often adhered to in turn by the Commission. ${ }^{45}$ Recent deportation cases involving second generation migrants, notably, Mostaquim ${ }^{46}$ and Beldjoudi, ${ }^{47}$ decided by the Court in 1989 and 1990 respectively, are also significant for their discussion of the ECHR article 8 right to family unity in connection with the deportation of family members. Despite inconsistencies, some common approaches in these decisions are worthy of consideration and are described below.

\subsection{The 'basic premise'}

That there is no 'right to immigrate' and that States are free to choose who may enter or remain within their territories within certain limits established by rules of international law is so frequently stated in the Strasbourg cases that it may be considered a basic premise, serving as a

\footnotetext{
34 Connelly, A.M., 'Problems of Interpretation of Article 8 of the European Convention on Human Rights', 35 ICLQ 567, 577 (1986).

${ }^{39}$ European Convention, ar. 8(2).

4) See, for example, Abdulaziz, above note 23

41 Storey, above note 4 , at 341 .

${ }^{42}$ For a comprehensive list of cases, see ibid., at 328-9.

${ }^{43}$ Abdulaziz, above note 23.

* Berrehab Case, 138 Eur.Ct.H.R. (ser. A) (1988) (hereinafter, Berrehab).

45 Storey, above note 4, at 328-9 implies that this may be the case or, at least, that the Commission 'assumes' that it follows a similar direction to the Court.

${ }^{45}$ Moustaquim Case, 193 Eur.Cl H.R. (ser. A) (1991).

47 Beldjoudi a France, 234 Eur.Ct.H.R. (ser. A) (1992); discussed further below.
} 
rationale by which the Court or Commission place limits on the right to family unity. Hence, in a case involving the rights of husbands in different families to immigrate under varying circumstances, the Court said it could 'not ignore that the present case is concerned not only with family life but also with immigration and that as a matter of well-established international law and subject to its treaty obligations, a state has the right to control the entry of non-nationals into its territory'. ${ }^{48}$

Case law reveals a conflict between an individual right to family unity and a State right of sovereignty, with State interests often weighing heavily in the solution. As one author notes, "The need to immigrate in order to fulfil the objective of family unity is in practice overruled by the individual State's sovereign right to decide who to admit to its territory'. ${ }^{49}$ Despite a tendency to give greater weight to State interests, the Court has noted that the extent of a State's obligation to admit relatives of settled immigrants to its territory will depend on individual circumstances. Determining whether an individual has a right to immigrate (or remain) on the basis of article 8 or whether a State's denial is justified, involves a balancing of considerations best understood by viewing the approaches of the Commission and the Court in individual cases.

\subsection{The approaches of the Commission and the Court}

Two basic approaches are followed by both the Court and the Commission. At the outset, both involve consideration of whether or not there is a family or family life under article 8 . Thereafter, one approach considers whether there has been an interference with this family life by a public authority and, if so, whether it can be justified under article 8(2). This has been characterized as the 'negative' approach, as States are required to abstain from any 'unjustified interference'. ${ }^{50}$ The second approach, better known as the 'positive obligation' requirement, is often followed in connection with a lack of efficient State procedures. It requires States actively to institute procedures or otherwise take positive measures to meet the requirements of respect for family life. As shown below, this 'positive' approach has important implications for a broader right to family unity.

\subsubsection{Defining 'family' for article 8 purposes}

Relations between immediate family members - spouses or parents and children, 'legitimate' or 'illegitimate' - constitute family life with little need for extensive inquiry. Outside of the nuclear family, the question of family life has traditionally been subject to closer scrutiny. It has been

\footnotetext{
$\checkmark$

* Abdulaziz, above note 23 , at 34

19 Perruchoud, above note 9 , at 512 .

5) Connelly, above note 38 , at 570 .
} 
held that ' $(t)$ he mere existence of a family relationship is not sufficient for the applicability of Article $8 \ldots$, and that some examination of the relationship invoked by an applicant, ie. whether there is a 'sufficiently close factual tie,' or a 'genuine tie,' is necessary in all Article 8 matters. ${ }^{5}$ Thus, the existence of a family for Article 8 purposes depends upon proof of certain 'ties' which, in turn, depends upon the nature of a given relationship. ${ }^{52}$ While these 'ties' are generally assumed for close family relations (ie. nuclear family members) unless proven otherwise, 'genuineness' in other relationships depends upon a variety of factual circumstances ranging from whether or not the concerned persons shared the same household ${ }^{53}$ to a consideration of economic dependency. ${ }^{54} \mathrm{Of}$ course, once a nuclear family has separated, be it for reasons of forced flight, migration, or even divorce, the family relationship will also be subject to an examination of 'genuineness'.

Thus, it is the social as opposed to the legal family which is relevant at the outset in the Strasbourg decisions. Both the Court and the Commission support the view that 'States should not define family for family reunification purposes by reference to "unyielding genealogical rules", ... (and maintain that) ... (t)he definition should be based on fact'. ${ }^{55}$ The Commission has stated that 'family life to be considered is ... de facto family life, ${ }^{56}$ and both Court and Commission have maintained that 'the fact of birth, ie. biological ties between mother and child ... creates family life in the sense of Article 8'; thus, protection is given to illegitimate children. ${ }^{57}$ Adopted children and parents are also considered to be a family. ${ }^{58}$ In Marckx $v$. Belgium, the Court held that 'ties between near relatives ...' such as grandparents and grandchildren comprise family life 'since such relatives may play a considerable part in family life'. ${ }^{59}$

The Commission has maintained that close de facto relationships which do not have the necessary legal characteristics for 'family life' may be

\footnotetext{
51 van Dijk and van Hoof, above note 10, at 379 (relying, in part, on Markx, above note 24 and Berrehab, above note 44).

s2 Ibid., at 380.

${ }^{53}$ See, for example, $X$ u Federal Republic of Germany, App. No. 3110/67, Y.B. Eur. Conz H.R. XI (1968) 449 (5 I8); $Y$ u. Surtzerland, App. Nos. 7289/75 and 7349/76, Y.B. Eur. Conu on H.R. XX (1977) $372(408-10)$.

st See $X$ a United Kingdom, App. No. 8157/78, (not published)

${ }^{55}$ Plender, R., 'Introductory Report on Human Rights of Aliens in Europe in Council of Europe', Division of Human Rights, Human Rights of Aliens in Europe, (1985), 49.

56 $X$ and $Y_{u}$ United Kingdom, App. No. 5302/71, Coll. 44 (1973) 29.

\$7 van Dijk and van Hoof, above note 10, at 378. Support for these contentions is drawn from the Markx case, above note 24; see also the opinion of the Commission (and cases mentioned therein), Markxx a Belgium, App. No. 6833/74, XVIII Y.B. Eur. Conu H.R. (1975) 248, 270.

${ }^{58} X_{\text {u }}$ France, App. No. 9993/82, 31 Dec. \& Rep. 241 (1983).

s9 Markx, above note 24, at 21 .
} 
covered under the right to respect for private life in article $8(1) .^{60}$ Thus, other 'family-like' relationships, not considered 'family' in a traditional sense), such as those between homosexuals or foster parents and children, may fall under the private life provision of article $8 .{ }^{61}$ Traditional European conceptions of family are not always decisive; even polygamous families have been granted a right to protection; ${ }^{62}$ however, States are by no means obligated to accept the practice of polygamy. On the other hand, 'extra-marital relationships may raise issues of family life, provided that the persons live together on a permanent basis and keep house jointly'. ${ }^{63}$ Cohabitation and financial independence have been factors considered apart from blood relationships; in some cases, the absence of these elements has resulted in the exclusion of complaints involving adult children, ${ }^{64}$ siblings, ${ }^{65}$ grandchildren,${ }^{66}$ and other extended family members, as well as adoptive children. ${ }^{67}$

In Abdulaziz and Berrehab, ${ }^{68}$ two leading family cases, the Court demonstrated a more liberal approach than previously with regard to its treatment of family life. In Abdulaziz, concerning the question whether a State's refusal to allow non-national male spouses (and spouses-to-be) of women 'lawfully settled' in the State to reside in its territory constituted a violation of article $8,{ }^{69}$ the Court held, among other things, that family life could be extended to include 'intended' family life, that is, fiancé(e) or marriages subject to validity problems):

Whatever else the word family may mean, it must at any rate include the relationship that arises from a lawful and genuine marriage, such as that

60 Raymond, J., La Suisse devant les onganes de la C.E.D.H. (Switzerland and the Organs of the European Convention on Human Rights) (Basel, 1979), 82. Art. 8(1) ECHR provides that '(e)veryone has the right to respect for his private and family life, his home and correspondence'. For an indepth discussion of the protection of private life, see Cohen-Jonathan, G., 'Respect for Private and Family Life', in R. St. J. Macdonald, F. Matscher, H. Petzold eds., The European System for the Protection of Human Rights, (1993), 405, 406-9.

${ }^{61}$ Regarding homosexuals, see, for example, $X$ a. the United Kingdom, App. No. 7525/78, 11 Dec. \& Rep. 117 (1981); on foster parents, see, $X$ V. Swizerland, App. No. 8257/78, 13 Dec. \& Rep. 248 (1978).

${ }^{62}$ Kahn u U.K., App. No. 2991/66, X Y.B. Eur. Conz on H.R. (1967) 478.

${ }^{63} X \& Y_{a}$ Swikerland, App. Nos. 7289/75 and 7349/76, XX Y.B. Eur. Conz on H.R. (1977) 372, 408.

${ }_{64} S$ \& $S$ a U.K., App. No. 10375/83, 40 Dec. E Rep. 196 (1984).

65 Family $X$ a U.K., App. No. 9492/81, 30 Dec. \& Rep. 232 (1982).

66 Uppal at al. a U.K. App. No. 8244/78, 17 Dec. \& Rep. 149 (1979).

$67 X \& Y_{\text {a }}$ U.K., App. No. 7229/75, 12 Dec. \& Rep. 32 (1977); for additional decisions concerning these categories, see Storey, above note 4, at 329, notes 8-14 and opinions cited therein. These decisions are often closely tied to the facts of the individual case: of. $X$ a France, App. No. 9993/82, 31 Dec. \& Rep. 241 (1983) where relations between adoptive parent and adoptive child are covered by art. 8 .

68 Abdulaziz, above note 23; Berrehab, above note 44 .

69 Abdulaziz, above, note 23, at 31 . More precisely, the Court stressed that the applicants were 'complaining not of being refused leave to enter or remain in the UK but, as persons lawfully settled in that country, of being deprived ... or threatened with deprivation ..., of the society of their spouses there.' Ibid., at 31 . 
contracted by Mr. and Mrs. Abdulaziz and Mr. and Mrs. Balkandali, even if a family life of the kind referred to by the Government has not been fully established. Those marriages must be considered sufficient to attract such respect as may be due under Article $8 .^{70}$

And, with more specific regard to the validity of a marriage contracted outside the United Kingdom,

The Court does not consider that it has to resolve the difference of opinion that has arisen concerning the effect of Philippine law. Mr. and Mrs. Cabales had gone through a ceremony of marriage ... and the evidence before the Court confirms that they believed themselves to be married and that they genuinely wished to cohabit and lead a normal family life. And indeed they subsequently did so. In the circumstances, the committed relationship thus established was sufficient to attract the application of Article 8."

In Berrehab, concerning the right of a divorced father to avoid deportation because of his close relationship with his daughter, lack of cohabitation did not prevent the Court from finding a family life in view of the circumstances:

It follows from the concept of family on which Article 8 is based that a child born of such a union (viz. a lawful and genuine marriage) is 'ipso jure' part of the relationship; hence, from the moment of the child's birth and by the very fact of it, there exists between him and his parents a bond amounting to 'family life', even if the parents are not then living together. ${ }^{\text {.2 }}$

Although the Court acknowledged that subsequent events could interrupt this bond, it considered the relationship between this applicant and his daughter as one rich with elements that bound them such that the 'ties of family life' were not upset by a lack of cohabitation. Despite the parents' divorce, the father made frequent and regular visits to his daughter, contributed to her education and otherwise acted in a manner evincing the persistence of a sound family relationship.

Berrehab and Abdulaziz have contributed to a broader notion of family life. Referring to them, one author has summarized the definition of family for future article 8 interpretation as follows:

... (T)he existence or non-existence of family life remains a question of fact depending upon the real existence of close personal ties. But to examine this question requires a more organic approach. This approach views family life in the round as a process with normal stages of development. At the centre, the family relationship of natural parent and child is pre-eminent. The concept can cover intended family life between couples. It can also cover ties persisting after

\footnotetext{
70 Abdulariz, above note 23 , at 32 .

71 Ibid., at 33.

12 Berrihab, above note 44 at 14.
} 
the breakdown of marriages (and) 'future relations' between a natural parent and a child may also be a proper focus. ${ }^{73}$

It is clear that the biological child-parent relationship and the traditional husband-wife one are fundamental for family life. Thereafter, in certain circumstances (for example, 'the existence of close personal ties'), the elements required for a family relationship may be broadened or, when the legal structure necessary for a family is lacking, a given relationship may be protected under article 8's private life provision. As the notion of family is, in itself, an evolving one and highly susceptible to changes in society's morals and values, this approach seems practical; a flexible, as opposed to a rigid definition, is clearly necessary to meet new and developing notions of family. ${ }^{74}$ Nevertheless, care must also be taken to avoid an overly broad description and to prevent the loss of a true and clear definition as this would be to the detriment of those seeking protection.

\subsection{Interference: Elsewhere versus the connections approach}

Until recently, it was generally held that an interference which violated article 8 is one which prevents the enjoyment of family life elsewhere. According to this theory, sometimes referred to as the "elsewhere approach,' expulsion or exclusion of a family member is legitimate if other family members can follow and if this can be 'reasonably expected' of them. ${ }^{75} \mathrm{~A}$ determination of reasonableness involves weighing the advantages and disadvantages to the concerned individual against the interests of the State served by its immigration policy. ${ }^{76}$ Criteria of relevance for deciding if there are obstacles to living elsewhere include, among others, consideration of one's ties with the State denying entry ${ }^{77}$ links with the foreign country; ${ }^{78}$ and the economic consequences of removal to another country. ${ }^{79}$ Among these, emphasis is placed on one's connections to a State: If an applicant has resided in a country for a considerable time and has founded a family there, it is more likely that

\footnotetext{
${ }^{73}$ Storey, above note 4, at 334-5; on 'future relations,' see case cited ibid, at 335.

74 A flexible approach is also needed in exclusion cases where, due to a forced separation, there may have been litule chance for a relationship to develop.

Agee a Unived Kingdom, App. No. 8416/79, 7 Dec. \& Rep. 164, 174 (1977); see also case law mentioned in Council of Europe, Case Law Topics No. 2, 'Family Life', (1972), 6-13.

${ }^{76}$ van Dijk and van Hoor, above note 10 , at 388 .

"The existence of close family members in the expelling country has long been considered relevant and persuasive when there is no serious crime involved; see, for example, $X$ a Federal Republic of Germany, App. No., 6457/73, I Dex. \& Rep. 77 (1974). In the East African Asians Cases, 3 E.H.R.R. 76, (unofficial Commission report) (1973), nationality was a factor, for additional cases concerning ties, see Storey, above note 4 , at 331 .

${ }_{78} X$ a Fedeal Republic of Gemany, App. No. 9478/81, 27 Dec. and Rep. 243 (1981).

79 Fanily $X$ a United Kingdom, App. No. 9492/81, 30 Dex. \& Rep. 232 (1983).
} 
partner and children have good reasons for not leaving. ${ }^{80}$ Similarly, it has been held that a prohibition of entry measure, 'can ... only be considered as interfering with a persons private or family life where the private and family life of that person is firmly established in the territory .... ${ }^{81}$

This manner of characterizing an interference is unique: With regard to almost any other basic right, an interference would constitute a restriction or limitation on that right. As is explained further below, the 'elsewhere approach' is problematic for a number of reasons and has been subject to much criticism. Among other things, it discriminates against couples of mixed nationality, and it is a difficult test because its determination is easily subject to varying judicial opinion. Not surprisingly, some Strasbourg cases, particularly more recent ones, have emphasized one's connections to a given territory and ignored the issue of obstacles to resuming family life elsewhere. ${ }^{82}$ The Court has evidenced a somewhat inconsistent approach with regard to the issue of interference. In Abdulaziz, it held that a lack of respect for family life could be sufficient for an article 8 violation without examining the question of interference. ${ }^{83}$ Subsequently, in Berrehab, the Court returned to the interference criteria, but stressed the connection factors (ties between father and child) while giving little attention to the 'elsewhere approach'. ${ }^{84}$ One might speculatc that the different approach here was because Berrehab dealt with a threatened deportation while Abdulaziz concerned the question of immigration. Still, it seems significant that the applicant in Berrehab had lived in the country for a considerable period of time, had employment, close family relations and was otherwise 'established' there. ${ }^{85}$

The different directions taken by both the Court and the Commission in determining whether there has been an interference indicate the need for re-examining and refining the current procedures. At the moment, it is difficult to say precisely how an interference will be decided in a family immigration matter. However, the fact that greater emphasis was given to connections as opposed to the elsewhere approach in both the Abdulaziz and Berrehab judgments represents an innovative approach which may be indicative of a new trend. Storey has suggested that because of the

\footnotetext{
p11) X a Federal Republic of Germany, App. No. 6357/73, I Dec. \& Rep. 77 (1975). See also Alam u U.K., App. No. 2991/66, 10 Y.B. Eut. Conu H.R. 478 (fact that a father had a long history as a 'permanent settler' was a decisive factor in an admissibility decision).

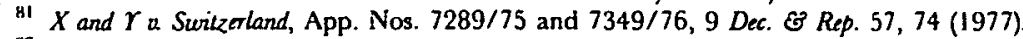

${ }^{82}$ This point is stressed by Storey, above note 4, at 332 and cases cited therein. See also Berrehab, above note 44

${ }_{83}$ Although the Court made clear here that this applied only if a State broadly overstepped permissible conduct.

Storey, above note 4 , at $335 \mathrm{fr}$.

${ }^{85}$ Bemehab, above note 44, at 16.
} 
problems inherent in the 'elsewhere approach', it might be better to get rid of it entirely and focus only on connections:

By starting from a conception of 'family life' as an organic process, the connections approach is able to avoid the internal inconsistencies to which the elsewhere approach is prey ... Giving more play to connections would not ... mean viewing the Convention as guaranteeing 'family life' rights to the fullest extent. But it would more safely ensure that the role of the Convention went beyond mere preservation of such rights in their barest forms. ${ }^{86}$

\subsection{Justifiable interference}

If an interference is found, a further inquiry is made into the possibility of its justification under article 8 , paragraph 2. Justification, in turn, depends upon whether the interference is 'necessary in a democratic society' in pursuance of one of the legitimate aims specified. These include, 'the interests of national security, public safety or the economic well being of the country, for the prevention of disorder or crime, for the protection of health and morals, or for the protection of the rights and freedoms of others' ${ }^{87}$

An interference with article 8 rights must not only be justified by a pressing social need, but must also be 'proportionate to the legitimate aim pursued'. ${ }^{8}$ The Commission and the Court apply a balancing formula here, between 'elements concerning respect for family life ... (and, among other things,) ... considerations relating to the proper enforcement of immigration controls' ${ }^{89}$ A tendency to find a connection between correct immigration practices and 'the prevention of ... disorder' has been prevalent in the case law. In Berrehab, the Court went so far as to note that a State's economic well-being within the meaning of article 8(2) could be a 'legitimate aim' on the basis of government concern over 'population density or the need to 'regulate the labour market'. ${ }^{\text {II }}$ However, even such a legitimate aim must be in proportion to the measures taken to achieve it. The deportation of the applicant father in the Berrehab case was a serious interference with family life; the government's economic interests, although legitimate, did not justify the interference.

Factors which come into play in the process of 'balancing' include the severity of the crime (when relevant), the obstacles to following the family member who is expelled or refused entry and, in cases involving married couples, the applicant's awareness of the risks involved at the time of the

Storey, above note 4 , at 338 .

ar European Convention, art. 8(2).

Beldjoudi, above note 47 , at 27

89 Xi U.K., App. No. 8245/78, 24 Dec. \& Rep. 98, 100 (1981); Berrehab, above note 44; For additional cases, see Storey, above note 4 , at 332-4.

917 Storey, above note 4 at 333 .

9) Berrihab, above note 44 , at 15 . 
marriage. Hence, in $X \& \mathcal{} Y$. Federal Republic of Germany, the deportation of a US Citizen married to a German national (with a child) owing to a conviction for dealing heroin was not an article 8 violation. Although there was an interference, it was in accordance with law and necessary in a democratic society for the prevention of disorder and crime'. ${ }^{92}$ In another case applying this same rationale, the Commission upheld the deportation of a Pakistani citizen for 'defying' immigration controls. In addition to its finding that $\mathrm{X}$, who had a spouse and children in the United Kingdom, was aware of the risks involved when he contracted his marriage, the Commission found no 'insurmountable obstacles' to the wife and children following him to Pakistan. ${ }^{93}$ Finally, with regard to the balancing formula, the Commission concluded that, 'there are no elements concerning respect for family life which might outweigh valid considerations relating to the proper enforcement of immigration control'. ${ }^{94}$

\subsubsection{Second-generation migrant cases}

Recent deportation cases involving second-generation migrants accused of criminal acts have regarded expulsion as a severe penalty warranted only under the most extreme circumstances. ${ }^{95}$ On first impression, it seems that the nature of the crimes involved may play a role here. However, a closer reading indicates that the Court and/or Commission heavily considered the overall situation of the applicants with respect to both their individual and family situations (that is, their ties) within the excluding State and the possibilities for continuing a comparable life-style elsewhere.

Moustaquim, a Belgian case, involved an applicant who had committed 147 offences, including robberies and thefts. The Court's conclusion that his deportation was not justified or 'proportionate to the ... aim pursued,' was based on his individual circumstances. Among other things, the applicant, although a Moroccan national, had lived in Belgium since before the age of two, residing with or close to his family (his parents and seven siblings). During this time, he made few visits to Morocco and

\footnotetext{
$92 X$ and $Y_{2}$ the Federal Republic of Germany, App. No. 7816/77, 9 Dec. \& Rep. 219, 221 (1977).

${ }_{93} X$ u United Kingdom, App. No. 9088/80, 28 Dec. E Rep. 160, 162 (1982).

Ibid.

${ }^{95}$ Mouslaquim, above note 46; Beldjoudi, above note 47. For in-depth discussion of these and similar cases, see Cholewinski, R., 'Strasbourg's 'Hidden Agenda'? The Protection of Second-Generation Migrants from Expulsion under Article 8 of the European Convention of Human Rights', 12 Net. Q.H.R. 287 (1994). Cholewinski defines second-generation migrants as persons who 'have resided in a country for a considerable period of time, without obtaining . . . citizenship (in) that country': ibid. 288. The second generation migrant cases suggest a more liberal direction and propose a standard comparable to the 'extreme hardship' standard applied in US deportation matters, on which see below. See also Nasri a France, Eur. Ct, H.R. (Council of Europe, July 1995) and The Chahal Famaly a The United Kingdom, App. No. 22414/93 Eur. Comm'n. H.R. (Council of Europe, June, 1995).
} 
received all his schooling in French. ${ }^{96}$ That family life elsewhere would be extremely difficult for him was corroborated by a doctor's report confirming that the applicant suffered from depression during an earlier period of deportation because of the disruption of family ties. With regard to the crimes committed, the Court stressed these had 'special features,' including that they had been committed while the applicant was a minor. ${ }^{97}$

In Beldjoudi, involving a threatened deportation to Algeria, the applicant's criminal record was more serious than Moustaquim's. Nevertheless, on balance, his ties to France outweighed the interests involved in his deportation. He had lived in France for 41 years, had most of his family there and had been married to a French woman for half of this time. Examining the possibilities for family life elsewhere, the Court agreed with the claim that expulsion would mean that the wife would be forced to live in a country where she had no substantial cultural contacts. This latter factor, constituting a 'serious interference,' led the Court to conclude that the intended expulsion 'might ... imperil the unity or even the very existence of the marriage'. ${ }^{98}$

In both the latter cases, the Court ultimately concluded that the governmental aims pursued were 'legitimate'; however, in light of the individual circumstances, the deportations were not proportionate to these aims and thus would, if executed, violate the applicants' article 8 rights. A similar analysis was maintained in June and July 1995, when the Commission and the Court, respectively, gave two further decisions concerning article 8 and the deportation of second generation migrants. ${ }^{(9)}$ In both cases, the threatened deportation was not proportionate to the legitimate aim of the State and thus not justifiable as 'necessary in a democratic society' under article 8(2).

In Chahal, ${ }^{100}$ the applicants comprised an entire family who alleged that a threatened deportation of one member would, among others, violate the article 8 rights of all family members. The main applicant was an Indian citizen who had resided in the United Kingdom for 19 years and established a family there. The government wished to deport him on national security grounds because of his alleged political involvement and activities as a 'Sikh militant'. ${ }^{101}$ The Commission held that a deportation would violate article 8 . Despite criminal charges, the applicant had not been convicted of a serious crime. His wife had also resided in the United

\footnotetext{
96 Moustaquim, above note 46 , at 14 .

97 Ibid, at 8, 19.

Soldjoud, above note 47 , at 28.

99 Nasri a France, above note 95 (hereinafter, Nasn); The Chahal Family a The United Kingdom, above note 95 (hereinafter, Chahal).

io Chathal, above note 95 .

101 Justification for the interference with family life was that the applicants continued presence in the UK was '... unconducive to the public good for reasons of national security and other reasons of a political nature...' Chahal, above note 95 , at 4 .
} 
Kingdom for about 19 years and his two children were born there. Although he had family in India, the Commission was convinced that if returned, there was a 'strong risk' that he would be arrested and detained and 'some risk' that he would be otherwise 'ill-treated'. This latter circumstance weighed heavily in the Commission's decision, as it noted that because of the risks involved, 'the deportation of the first applicant would almost certainly lead to a permanent break up of the family'. ${ }^{102}$

In $\mathrm{Nasri}^{103}$ the threatened deportation was based on a gang-rape conviction. The severity of such a crime and the threat it posed to public order was not questioned. However, there were extenuating circumstances, among them the fact that the applicant was deaf and dumb since birth, although capable of minimal comprehension and communication with family and friends, and, because of inadequate schooling, a complete illiterate. For the Court, such circumstances heightened the importance of the family with whom the applicant had always lived. Also significant was that all the applicant's schooling occurred in the expelling country, and that he could not understand the language of the country to which he would be deported.

Considered together, the second generation migrant cases confirm that under the European Convention on Human Rights, family ties and an individual's connections to an expelling State weigh heavily in deportation matters. Although the 'elsewhere approach' has not been abandoned, it seems to play a less significant role. More importantly, these cases establish a pattern whereby, in particular circumstances, State interests, although acknowledged as 'legitimate,' do not override competing individual interests.

Similar reasoning has not been followed in cases where deportation was not at issue. In Abdulaziz, for example, the Court did not look into the hardships involved for a United Kingdom resident originally from Malawi to follow her spouse to Portugal, despite the fact that she also had close family in the UK, spoke no Portuguese and had no other significant connections to Portugal. Even though deportation was not an issue in Abdulaziz, the European Commission and European Court of Human Rights have been criticized for taking a somewhat inconsistent approach in the article 8 cases. $^{104}$ On the other hand, in deportation cases involving second-generation migrants, there is a fairly constant tendency to look at the 'whole picture' with regard to an applicant's family situation within the excluding State; and, in many (but not all) cases, to examine further the possibilities for family life elsewhere. Consideration of whether or not the obstacles to living elsewhere are

\footnotetext{
102 Ibid., at 29. The Commission's conclusion that a deportation would involve an art. 3 violation here was significant for its determination regarding art. 8 .

103 Nasri, above note 95.

${ }^{104}$ See, for example, Storey, above note 4 and Connelly, above note 38
} 
'insurmountable' may also depend upon the existence and extent of family connections in the excluding State. ${ }^{105}$

Although the notion of family and family ties are stressed in these cases, the approach in deportation matters sometimes gives greater consideration to individual roots developed in the country of residence, as opposed to family life, when weighing these against the aims of the deporting authorities. As one author notes, in deciding whether a deportation is necessary in a given society, more attention tends to be given to such elements as schooling, social ties, culture and language differences resulting in a conclusion based on the status of the individual. Because of the length of time such persons have resided in the expelling State, they may, in effect, be treated as de facto citizens. ${ }^{106}$

In some cases, it is difficult to determine the relevance of family life. One might speculate that the family rights of a repeated offender who has seldom lived at home are not violated when he is forced to return to his country of origin. The family of such a person may not be terribly concerned about his or her removal, although, of course, the opposite may also be true. More importantly, however, regardless of whether the underlying considerations are related to the family or the individual, another aspect must be taken into account. When a person has lived in a country for a long time, grown up in the culture and its language, studied, worked there, and has no real or substantial connection with the country of origin, there can be no legitimate reason to send him or her back; it is also not reasonable or fair to force the other country to receive such a person. This situation is illustrated in the following comment from Beldjoudi v. France.

I think that expulsion, especially (as in the present case) to a country where living conditions are markedly different from those in the expelling country and wherc the deportee, as a stranger to the land, its culture and its inhabitants, runs the risk of having to live in almost total isolation, constitutes interference with his right to respect for his private life. ${ }^{107}$

The penalty of expulsion and its consequences for the individual who has lived all or most of his or her life in the expelling country is clearly extreme. Nevertheless, the severity of a loss of family life and its significance not only for the deportee but also for the family members left behind

105 In applying the 'elsewhere approach', the extent of family outside the country is often of relevance; in Moustaquim, above note 46, for example, the Court noted that the applicant had no roots outside the country where his family lived.

106 Cholewinski, above note 95 at 298.

107 Belfjoudi, above note 47 , at 38 (Manens, J., concurring). ECHR art., 8(1) provides for 'a right to respect for private and family life'. Private life is not limited to individual considerations, and the Commission has acknowledged that it can also apply to a close de facto relationship which does not fit into the legal definition of a family. Cohen-Jonathan, 'Respect for Private and Family Life in The European System for the Protection of Human Rights', above note 60, at 407. 
should not be minimized. When close family members are unreasonably or unjustly prevented from reuniting or forced to leave a country, it is often the entire family that suffers. In this connection, the 1989 Convention on the Rights of the Child is relevant, as an interference with family life may result in a violation of its provisions ensuring that a child, 'shall not be separated from (its) parents'. ${ }^{108}$ When considering the effect of a potential separation of family members, it is thus essential to look beyond the individual loss or harm and consider its significance for the entire family. There are reasons why the drafters of article 8 provided separately for both private and family life; it would be erroneous to minimize the importance of the latter provision, or to blend the two together.

\subsection{Positive obligations}

As opposed to asking if there has been an 'interference' with family life, the 'positive obligation' approach asks whether a State must, in the circumstances, take some positive steps to protect family life under article 8. It has evolved from efforts to give meaning to the notion of 'respect' and its requirements vary. As noted by the Court in Abdulaziz, 'the extent of a state's obligation to admit to its territory relatives of settled immigrants will vary according to the particular circumstances of the persons involved'. ${ }^{109}$

In many of the cases which have applied this approach, States are directed to implement procedures necessary to protect family life. Thus, for example, it has been held that the notion of 'respect' for family life obliges contracting States to create effective means by which an applicant claiming to be the father of a child could establish his biological tie, ${ }^{111}$ while in another matter, a State was required to create procedures enabling couples to separate."'

The first clear statement regarding the requirement of positive action by States was in Marckx, ${ }^{112}$ which called for the termination of State procedures that discriminated against illegitimate children. In Marckx, the Court described the positive obligation as one which may arise in addition to the requirement that States abstain from arbitrary interference. ${ }^{113}$ It also held that the requirement of respect for family life implied an obligation that States 'allow those concerned to lead a normal family life', and 'render possible as from the moment of birth the child's integration in his family'. ${ }^{114}$ This comment has provided grounds for a

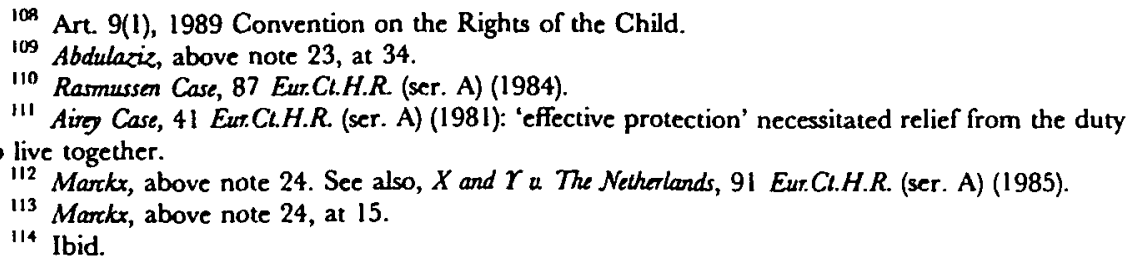


broader interpretation of article 8 , particularly with regard to its implications for marriages between citizens and non-nationals and the general rule that States are not obliged to grant non-nationals a right to stay in such cases. ${ }^{115}$

Applying the positive obligation approach in Abdulaziz, the Court gave reasons for confirming the State's denial of entry under article 8 , including, among others, that the applicants had failed to present sufficient evidence of obstacles to living elsewhere, and that, at the time of their marriage, they were aware of the risk that their spouses might not obtain permanent residence status. The Court held that, in the circumstances, the State was not under a positive obligation to secure family life in a preferred country of residence. ${ }^{116}$ It did not discuss the effects on family life for those refused permission and whether this might be an interference warranting justification under article 8(2). Despite its findings with respect to article 8, the Court concluded that the respondent State's denial of status was unlawful: Because male immigrants were expressly given easier access to bring in their spouses than females, there was a clear case of sexual discrimination as a result of which the Court found a violation of article 8 together with article $14 .^{117}$

Although it took a rather conservative approach here with respect to positive obligations, the Court left a door open for subsequent decisions involving similar issues by noting that, 'there may be circumstances in which a contracting State should admit to its territory the spouse of a settled immigrant in order to secure to the couple effective enjoyment of their family life'. ${ }^{118}$ This reinforces a broader interpretation of the positive obligation requirement originally set forth in the Marckx decision. It implies that a State should take whatever action is needed to promote human welfare and dignity and represents a 'social view of human rights' in which the State plays a major role; ${ }^{119}$ however, it is the family, as opposed to the State, which receives precedence. It has been proposed that the positive obligation approach may, together with recent case law developments, eventually lead to full application of the right to respect

\footnotetext{
115 See Cvetic, above note 2, at 65 Iff, noting that almost all human rights instruments which guarantee a right to marry impose some obligations on States with regard to family protection. He further remarks that the positive obligation approach allows for a liberal construction of the right to marry and found a family which, in connection with recent Strasbourg case law developments, may eventually lead to acceptance of a citizen's right to respect for his family life, even if he or she marries a non-national.

${ }^{116}$ Abdulaziz, above note 23, at 34 .

11 Ibid. at $35 \mathrm{ff}$. With regard to a State's obligation not to discriminate on grounds of sex (in connection with admission policies), see also, East African Asians a Urited Kingdom, 3 E.H.R.R. 76 (unofficial Commission Report) (1973); Aumeereddy-Cziffra and Others a Mauritius, UN Human Rights Commirtee (Communication No. R. 9/35) (Apr. 1981).

118 Abdulaziz, above note 23 , at 34 .

${ }^{119}$ Connelly, above note 38 at $574-5$. For further discussion of cases focussing on positive obligations, see $572-5$.
} 
for family life for marriages between citizens and non-nationals. ${ }^{120}$ Because it is an obligation which, in some circumstances, gives greater significance to families than countervailing State interests, it may also have positive implications for future family reunification issues.

\section{The right to family unity in the United States of America}

\subsection{Historical overview: plenary power and family unity}

A constitutionally protected right to freedom from State interference with family life is well established in the US Supreme Court's case law. ${ }^{121}$ Although aliens do not enjoy the same degree of protection as citizens, they have not traditionally been denied family rights. From early on, US courts have recognized, with the exception of Congressional intent to the contrary, that a right to family unity is a 'natural right':

... a Chinese merchant who is entitled to come into and dwell in the United States is thereby entilled to bring with him, and have with him, his wife and children. The company of the one, and the care and custody of the other, are his by natural right: and he ought not to be deprived of either, unless the intention of Congress to do so is clear and unmistakable. ${ }^{122}$

Historically speaking, the US approach to the issue of family rights in connection with immigration matters has varied. Close to the turn of this century, the plenary power doctrine, which limits judicial authority in immigration matters and transfers it to legislative and executive branches, replaced an earlier period of broader respect for aliens' rights. ${ }^{123}$ This power of Congress to regulate immigration is considered as a power incident to State sovereignty; it specifically empowers the legislature 'to regulate the entry and stay of aliens as well as the process through which aliens become naturalized citizens ...'24 As shown below, however, congressional power over the admission of aliens, although broad and characterized as 'absolute', is not without limitation, particularly when Congress sets procedures which do not comply with due process or 'minimum standards of fairness'.

${ }^{120}$ Cvetic, above note 2 , at 655 .

121 Moore a East Cleveland, 431 US 494, 531, citing additional cases for same proposition.

122 In re Chung Toy Ho and Wong Choy Sin, 42 F.2d 398, 400 (1890); as used here, 'unity' seems to include, or to be synonymous with, the concept of reunification.

123 The plenary power doctrine was originally articulated in Chae Chan Ping u US, 130 US 581 (1889) and Fong Tue Tung a US 149 US 698 (1893). A broad federal power over the admission of aliens has been recognized by case law for a longer time, but Congress was not especially active in regulating immigration until the late 1800 s. Rotunda, Ronald D. and Nowak, John E., Treatise on Constivutional Law, Substance and Procedure, (2nd. ed., 1992), vol. 4, 600.

${ }^{124}$ Tribe, Laurence H., American Constitutional Low, (2nd ed., 1988), 358. 
At its height, the plenary power doctrine was responsible for extensive limitations on judicial review in matters in matters affecting non-nationals, resulting in greater restrictions on aliens' rights. This sometimes had repercussions for citizens, for if Congress had reasons so to regulate, even they could be deprived of close family. The 1924 Immigration Act, for example, prohibited the unification of children and spouses of Asian origin with their citizen or resident alien parents or spouses. ${ }^{125}$

A system imposing numerical limitations on immigrants was first developed by Congress in the early 1920s. Initially, it only afforded the possibility for family unification to a few classes of citizens and residents. Following the Second World War, the possibilities for family unification improved for both aliens and citizens, although '(a) distinction between the treatment of relatives of citizens and relatives of permanent resident aliens remains fundamental in current immigration law.'126

Because of judicial deference to Congress in immigration matters, constitutional claims to family unity (first brought in the 1950s) have seldom succeeded. Earlier cases were rejected with little explanation. In US ex rel Knauff v. Shaughnessy, ${ }^{127}$ the exclusion of the wife of a US citizen on grounds related to national security was upheld without consideration of the rights of the US citizen spouse. In a later case, it was alleged that the deportation of a resident alien spouse would violate due process rights by 'potentially' destroying a marriage. The Court disagreed, holding that although the marriage was burdened, it was not destroyed and noting further that the residing spouse had the option to follow. ${ }^{128}$

Since the early 1970 s, the force of the plenary power doctrine has lessened as judicial intervention, though still limited, has increased where the constitutional rights of aliens are at issue. ${ }^{129}$ Notwithstanding heightened attention to the issue of family unity, the plenary power doctrine has continued to dominate, as illustrated in Fiallo v. Bell:

At the outset, it is important to underscore the limited scope of judicial inquiry into immigration legislation. This Court has repeatedly emphasized that 'over no conceivable subject is the legislative power of Congress more complete than it is over' the admission of aliens. Our cases 'have long recognized the power to expel or exclude aliens as a fundamental sovereign attribute ... largely immune from judicial control'. ${ }^{130}$

Decided in the late 1970s, Fiallo has continued to be a leading case for

125 Guendelsberger, above note 30, at 256.

126 Ibid., at 256; see also Noel a Chapman, 508 F.2d 1023 (2nd Cir., 1975), cert. denied, 423 US 824 (1975)

${ }_{127}$ Knauff a Shaughnessy, 338 US 537 (1950).

124 Swartz a Rogers, 254 F.2d 338 (D.C. Cir. 1958). 733.

229 Rosenfeld, J., 'Deportation Proceedings and Due Process of Law', 26 Col. H.R. Law Rea 679,

I') Fiallo a Bell, 430 US 787, 792 (1977) citing, among others, Oceanic Navigation Co. u Stranahan, 214 US 320, 339 (1909); accord, Keindienst a Mandel, 408 US 753, 766 (1972). 
decisions involving distinctions between the rights of aliens and citizens. ${ }^{131}$ The case involved a challenge to the constitutionality of an immigration law which failed to exempt illegitimate alien children from numerical limitation requirements if they were coming to join their citizen-fathers; if the same children were joining their citizen-mothers, the exemption was granted. The petitioners argued that the provision violated due process and equal protection rights, and that it implicated the fundamental constitutional interests of United States citizens and permanent residents in a familial relationship'. ${ }^{132}$ The Court was not persuaded. It upheld the constitutionality of the statute on the basis of the plenary power doctrine, stressing the limited scope of judicial inquiry into immigration matters. The decision was grounded upon principles of State sovereignty:

We are dealing here with an exercise of the Nation's sovereign power to admit or exclude foreigners in accordance with perceived national interests ... (L)imits and classifications as to who shall be admitted are traditional and necessary elements of legislation in this area. ${ }^{133}$

In dicta, the Court referred to the legislative history of Congressional concern with keeping families of citizens and aliens together, and acknowledged that the statutory provisions in question were aimed at family reunification. ${ }^{134}$ Although fathers of illegitimate children are no longer excluded from preferential treatment, Fiallo remains important for demonstrating the extent to which the Court has deferred to Congress in immigration matters. The suggestion that the provision at issue involved double-barrelled discrimination which implicated constitutional rights 'without furthering legitimate governmental interests' ${ }^{135}$ did not override sovereignty notions, as was the case in Abdulaziz. In the latter case, the European Court of Human Rights found that exclusion of the husbands was within the sovereign power of States to set limits on entry, but that the discriminatory nature of a law which provided no similar exclusion for the opposite sex was unacceptable. In contrast, the Fiallo Court found a justification for the legislation, which it noted was anyway not within the province of the Court to closely examine. ${ }^{136}$

In applying the plenary power doctrine, the deterrence of fraud and the underlying aim of limiting the number of immigrants often serve as justifications for limiting family unification. In Noel v. Chapman, ${ }^{137}$ a federal

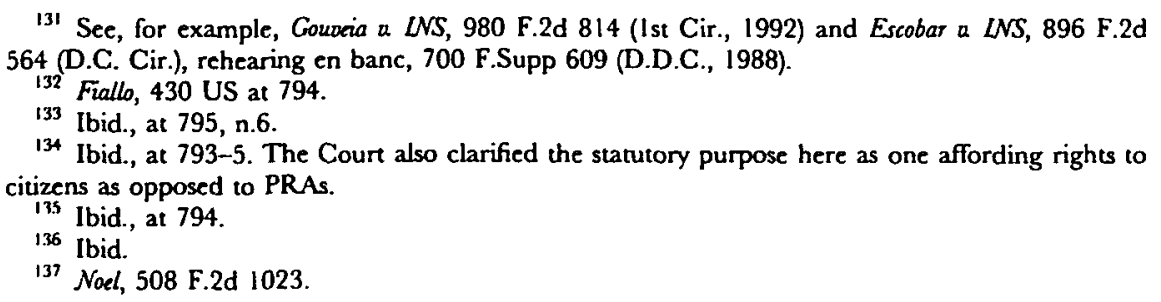


court denied an equal protection challenge to a statutory distinction between aliens married to citizens and those married to permanent residents. The court held that a family integrity theory would not support a constitutional right for resident alien wives to keep their alien husbands in the US while awaiting US visas, because of the potential for fraud:

... the statute had a rational and substantial relationship to the purpose for which it was enacted - to protect the American economy by discouraging the arrival of aliens who were coming in large numbers and remaining illegally in the expectation of a marriage that would assure their continuing residence here. $^{138}$

In spite of the plenary power doctrine and the efforts to deter fraud, family reunification remains a highly valued objective in the US, resulting in a tension in the law not unlike the conflict existing in European law between State sovereignty and the rights attaching to family protection. This is well illustrated in cases following Fiallo. In Kaliski v. District Director, for example, a federal court emphasized the 'humane purpose of the Act to reunite families', and held that there was no rational basis for an arbitrary distinction which detracted from the 'purpose of the Act ... to prevent the continued separation of families'. ${ }^{139}$ Other federal cases have similarly given more weight to family reunification, noting that it is 'the most important policy underlying the granting of visas under the US immigration laws. ${ }^{(1)}$ Hence in some circumstances, family reunification goals prevail. As in the European cases, therc is often a balancing of the interests involved, together with a consideration of the individual situation. In many cases, the constitutionality of a statutory condition precedent to obtaining citizenship is at issue, and the court must determine if there is a rational basis for such provision. ${ }^{141}$

\section{2 'Family' defined: Legislation and case law}

\subsubsection{The legislative approach}

Immigration into the US is regulated pursuant to the Immigration and Nationality Act (INA) as amended by the Immigration Act of 1990 (1990 Act). ${ }^{142}$ Pursuant to the 1990 Act, immigrant visas are divided into three

134 Ibid., at 1029.

139 Kalisti, 620 F.2d 214, 217 (9th Cir., 1980).

140 Delgado a LNS, 473 F. Supp. 1343, 1348 (S.D.N.Y., 1979) quoting Lau a Kilgy, 563 F.2d 543 (2nd Cir., 1977).

$1+1$ See, for example, Ablang a Reno, 52 F.3d 801 (9ch Cir., 1995), denying a constitutional challenge to a statutory requirement of proof of paternity for naturalization of illegitimate children of US citizen fathers. The court found a rational basis for the statute ultimately characterizing it as a reasonable measure for deterring fraud; cf. Kalista, 620 F.2d 214, where the Ninth Circuit was not convinced that a restrictive interpretation of a stante would alter the possibility of fraud and emphasized family unity as a further consideration in upholding a liberal interpretation.

${ }_{142}$ See Immigration and Nationality Act, above note 25 and Immigration Act of 1990, above note 26 . 
areas: family-based, employment and diversity (reflecting the different interests behind US immigration policy). ${ }^{143}$ Significantly, the law contains no limits on the entry of immediate relatives of US citizens, which includes children, spouses and parents of US citizens over age 21. Under the 1990 Act, widows and widowers of US citizens married at least two years before the death of their spouse are also included, provided they comply with filing requirements; ${ }^{144}$ if they marry, however, the immediate relative status terminates. With regard to other family members (or 'nonimmediate family'), the statute contains a preference system according to which a designated number of relatives of US citizens and resident aliens are allowed to enter each year. ${ }^{145}$

Among other things, the 1990 Act provides for an increase in family based immigration, and it is hoped that the new Act will 'expedite the reunion of immigrant families in the US' by increasing the number of family based immigrants in general. ${ }^{146}$ Thus far, however, its impact has been minimal in light of the vast numbers of people waiting to join their families in the US.

\subsubsection{The judicial approach}

Although US courts have yet to define family, the decisions provide a basis for understanding which relationships will be given protection. The courts have also filled some of the gaps left open by the legislature. For example, the term 'spouse,' which is not defined in the immigration laws, is defined in case law as 'a party to a valid marriage that has not been legally terminated'. ${ }^{17}$ Marriage tends to be defined more in terms of its validity; generally, a marriage is valid if it was valid at the place of inception, and it does not violate US public policy. Certain requirements for a valid marriage have changed, however; cohabitation or a 'viability test,' for example, are no longer necessary. ${ }^{148}$

Many cases render a traditional concept of family as 'persons bound together by marriage and kinship ties'. ${ }^{149}$ Constitutional protection for children and spouses is least problematic, although as is the practice of

143 Leiden, W.R., 'Highlights of the US Immigration Act of 1990', 14 Fordham Intemational Law Joumal 328, 329 (1990-91).

ith $1990 \mathrm{Act}$, above note 26, Sec. 101(a) adding INA Sec. 201(b)(2)(A)(I).

145 Basically, the preference system for family based immigration under the 1990 Act is as follows: First preference is given to adult unmarried sons and daughters of US Citizens; second preference is given to spouses and unmarried sons and daughters of permanent resident aliens (under the 1990 Act, more visas were made available for this category than previously); third preference is given to married sons and daughters of US citizens; and fourth preference is given to brothers and sisters of US citizens. (1990 Act, above note 26 ).

146 Leiden, above note 143, at 329.

147 Matter of P-, 16 IEN Dec. at 613 (BLA 1980).

148 Matter of Mckee, 17 IEN Dec. 332, 334 (BLA 1980); Matter of Peterson, 12 IEN Dec. 663 (BLA 1968).

${ }^{49}$ killage of Belle Tem a Boraas, 416 US I, 9 (1974). 
the European Court and Commission, US courts also examine the existing relationship, especially that between parent and child: '(T)he extent of constitutional protection granted to the parent-child relationship depends on the degree to which the parent accepts some measure of responsibility for the child's future'. ${ }^{150}$ It has been argued that constitutional protection should only be granted when parents have taken part in the responsibilities of parenthood; however, in exclusion cases, the immigration laws may be the reason for a lack of contact. Hence, particularly where parents petition for the entry of a child, it has been suggested that 'the biological tie should be sufficient to bring the relationship within those that are constitutionally protected'. ${ }^{151}$ Thus, in Palmer v. Reddy, ${ }^{152}$ a US Court of Appeals construed the INA statute concerning visa preferences for stepchildren to require only marriage to the natural parent, regardless of the parent-child relationship. The court criticized the Immigration and Naturalization Service's approach, which had required a showing of parental interest, and maintained that no such conditions applied.

Constitutional protection for family members other than parents, children and spouses is more complicated. For example, it has been held that there is no constitutional protection for the bond between siblings. ${ }^{153}$ The court noted here that broadening constitutional protection to cover family members beyond the parent-child relationship would go too far and preclude 'a principled way of limiting' such protection for family relationships. ${ }^{154}$ In other areas, the Supreme Court has granted protection to de facto parent-child ties. In Moore v. City of East Cleveland, the Court held that a grandmother who filled a parental role was a constitutionally protected family member. The right to live together as a family went beyond the nuclear family,

... since the Constitution's protection of the sanctity of the family was deeply rooted in the nation's history and tradition, and since such tradition was not limited to respect for the bonds uniting the members of the nuclear family, but extended as well to the sharing of their household with uncles, aunts, cousins, and especially grandparents. ${ }^{155}$

Although interesting from many aspects with respect to its interpretation of family and the extent of constitutional protection it is entitled to, Moore involved the rights of citizens as opposed to immigrants. It is doubtful

150 Lehr a Robertson, 463 US 248 262, (1983).

151 Guendelsberger, above note 30, at 265.

152 Palmer a Reddy, 622 F.2d 463, 464 (9th Cir., 1980).

153 Fiallo a City of Milwarke, 746 F.2d 1205 (7th Cir., 1984); however, brothers and sisters of US citizens are in the 4th preference category under current immigration laws.

154 Bell a City of Milwauter, 746 F.2d 1205, 1247-8 (7th Cir., 1984), citing Sanchez a Marquez, 457 F.Supp. 359, 362 (D. Colo. 1978). Under the 1990 Act, not only brothers and sisters of US citizens, but also widows and widowers may be eligible. Nevertheless, constitutional protection remains limited in cases where relationships other than that of parent-child and spouse are concerned.

I55 Moore, 431 US at 531-2. 
that the courts would rule likewise in immigration matters; still, cases do arise resting on equitable principles and reflecting the same underlying interests (for example, protecting the sanctity of the family) as those set forth in Moore. This is best seen in deportation matters: In Antoine-Dorcelli v. $L N S,{ }^{156}$ for example, it was held that the deportation of a Haitian woman who had lived with a US family from the age of 7 and later became a family servant should be suspended, given the nature of her relationship to the family. Because the petitioner considered herself a family member for approximately 30 years, her separation would result in an 'extreme hardship' in that her 'true and only family relationship' was with the US family. ${ }^{157}$

Dorcelli is unquestionably a unique case, but it illustrates the extent to which family and family ties can be relevant in this area. When the question of relief from deportation of a family member is at issue, the relationship is more closely examined. Current immigration law requires, among others, a showing of 'family ties within the United States', 'residence of long duration in the US' and 'evidence of hardship', for either the deportee or his or her family members who would be left behind, before granting relief. ${ }^{158}$ US law in this area explicitly reflects a concern for the whole family, contrasting with the Strasbourg cases noted above, which tend to focus on individual roots developed in a country of residence and often ignore the repercussions for the rest of the family. Perhaps this is an area where the European Court and Commission can learn from the US approach.

Otherwise, however, cases regarding US family immigration matters are similar to the European cases described above. US courts also scrutinize family ties and determine if they are sufficiently close such that a forced separation would unreasonably burden the family relationship. As seen above, family ties weigh heavily in deportation matters, and there is a similar tendency to balance State and individual interests. Serious crimes, including certain classes of crimes involving 'moral turpitude' or drug related offences, may tip the scales and result in a denial of relief from an order of deportation. ${ }^{159}$ In Gouveia v. $L N S$, ${ }^{160}$ a petitioner, who had previously pleaded guilty to rape and indecent assault, sought relief from a deportation order based on a number of 'positive equities',

156 Antoine-Dorelli a LNS, 703 F.2d 19 (1st Cir., 1983).

157 Ibid., at 21

158 Matte of Marin, $16 / \mathcal{S}^{3} \mathcal{N}$ Dec. 581 (BLA 1978). A list of standards for evaluating relief from deportation under section 212(c) of the Immigration and Nationality Act was formulated in this case and subsequently approved and applied in a number of circuit court matters, most recently, Gouveia a LNS, 980 F.2d 814 (1st Cir., 1992)

159 Bardett, Robyn J., 'Immigration Law - Waivers of Deportation - Failure to Delineate Standards for Convicted Aliens Seeking Waivers of Deportation Renders Relief Illusory, Gouveia u LVS, 980 F.2d 814 (1st Cir., 1992)', 17 Suffolk Transmational Law Review 551 (1994).

Ió Gouvia, 980 F.2d 814 . 
including his long term family ties, steady employment and lengthy residency in the US. These were considered insufficient to overbalance the criminality involved, particularly because of the 'heinous nature' of the crimes committed, his deportation was upheld. Thus, as in Europe, an interference with family life is justified where a prevailing State interest (article 8(2)) is found to be legitimate. Finally, as shown below, the tension between individual rights and the plenary power doctrine is a dominating feature in these matters, a characteristic comparable to the conflict between individual and State in European Law.

\subsection{Plenary power and the approach of the US courts: The substance-procedure distinction}

Outside the immigration realm, the constitutional rights of aliens are determined in a manner similar to those of citizens. With respect to procedural due process rights, US Courts have traditionally indicated that even in immigration matters, they 'would not totally abandon their role as guardians of aliens' rights'. ${ }^{161}$ Thus there remains a grey area in which the rights of aliens in immigration matters may still be deserving of judicial review and of constitutional protection equal to that of citizens. Where procedural due process rights have been violated, there is an exception to the plenary power doctrine which allows for judicial review and the application of a 'strict scrutiny' test for determining whether or not a given procedure violates due process. On the other hand, a less stringent standard of review - a 'rational basis' test - is applied in immigration matters involving substantive due process violations. ${ }^{162}$

Two fairly recent cases illustrate the reasoning followed in the application of these tests. Both involved decisions pursuant to section 5(b) of the Immigration Marriage Fraud Amendments (IMFA), which provides that aliens who marry US citizens during the pendency of a deportation proceeding must reside out of the US for two years before a petition for immediate relative status will be considered by the INS.

In Manwani v. US Department of Justice, $L N S,{ }^{163}$ the petitioners, a US citizen and her foreign husband, challenged the constitutionality of this provision. The couple had married during deportation proceedings against the husband for overstaying his visa, as a result of which he was required to reside outside the US for the two-year period. The court ruled that the statute, as applied to these petitioners, invoked procedural due process

161 Motomura, above note 32, at 1648.

162 Substantive provisions grant a particular status while procedural ones concern 'how or when a decision is to be made to award the previously authorized substantive status.' Escobar a LNS, 896 F.2d 564, 567 (D.C. Cir.). For a discussion of the substantive-procedural distinction as it has been developed in the case law, see Manwani a US Dept of Justice, LNS, 736 F.Supp. 1367, 1375-7 (W.D.N.C. 1990).

${ }_{163}$ Manwari, 736 F.Supp. 1367. 
rights warranting judicial review and the application of a strict scrutiny standard of review. A lengthy analysis of the difference between substantive and procedural classifications ensued. The court compared Fiallo, noting the distinction drawn there between statutes which 'set forth categories of familial relationships' and those which 'establish procedures designed to prevent circumvention of lawful admission requirements,' the latter being subject to strict constitutional scrutiny. ${ }^{164}$ As applied here, section 5(b) was found to penalize the exercise of a fundamental right, namely, the right to marry. Compelling these plaintiffs to reside elsewhere would 'interfere with (their) ability to have a family and ... impose enormous and unwarranted hardships on their marriage'. ${ }^{165}$

The Manwani Court was unusually liberal in more than one respect. It disagreed with a previous line of cases which held that a citizen-spouse did not have a constitutional right to have his or her alien spouse remain in the US and maintained, instead, that such reasoning ignored the basic issue of whether a 'protected interest' was 'burdened' by section 5(b):

Restrictions on marriage are subject to the most exacting scrutiny. A governmental burden on the right to marry need not amount to an absolute prohibition in order to constitute an impermissible interference with marital association. ${ }^{166}$

Finally, the court noted that section 5(b) also resulted in a deprivation of Ms. Manwani's property right to the immediate relative status of her spouse. Pursuant to statute, once the INS finds that a marriage between an alien and a citizen is bona fide, it is obligated to grant immediate relative status. ${ }^{167}$ Because section $5(\mathrm{~b})$ interfered with this right without allowing for a hearing, there was a further violation of due process because of a lack of 'constitutionally adequate procedures'. ${ }^{\text {is }}$

Azizi v. Thomburgh, a case with a similar fact pattern, was decided by the US Court of Appeals in the same year as Manwani. ${ }^{169}$ Here, the court interpreted section $5(b)$ as substantive and thus subject only to a rational basis review. The requirement that the alien live out of the US for two years was found to be 'rationally related' to Congress's goal of eliminating marriage fraud and was thus upheld against a constitutional challenge. Since the provision created a substantive as opposed to a procedural classification, the alien plaintiff was not entitled to a hearing with respect

164 Ibid., at 1375 .

165 Ibid., at 1371 .

166 Ibid., at 1379 .

167 Ibid., at 1381, citing Escobar a LNS, 896 F.2d at 569.

IfA Ibid. The notion of a property right to immediate relative status which cannot be denied without due process of law is cited in both statutory and case law. The alien must qualify as an immediate relative under 8 USC 1151 (b) which then mandates the approval of a citizens visa petition. For an in-depth discussion of this subject, see Whinnery, N., "The Immigration Marriage Fraud Amendments - Substantive or Procedural Provisions?' 64 Temple Law Reviaw 1081, $1090 \mathrm{fr}$. (1991).

169 Azizi a Thomburgh, 908 F.2d 1130 (2nd Cir., 1990). 
to the loss of his immediate relative status. As in Fiallo, the court followed the 'limited judicial scrutiny' line of reasoning.

Critics of Azizi have maintained that because section 5(b) prolongs the assertion of a statutory right, it is procedural and thus deserving of the same treatment as in Manwani:

The Azizis sought to protect the right to immediate relative status specifically granted by the INA to bona fide spouses. The court should have acknowledged that the provision implicated previously protected liberty interests of the right to marital association and of the right of a US citizen to remain in the US. A better analysis would hold 5(b) unconstitutional under a strict scrutiny standard. ${ }^{170}$

In a dissenting opinion, Judge Cardamone also stressed the procedural nature of the statute. Among other things, he noted that there was an 'unconstitutional burden on the right to marry' and that the statute's potential for avoiding fraud was doubtful. ${ }^{171}$

As the above cases illustrate, the determination of whether an alleged violation is substantive or procedural is difficult. Section 5(b), for example, may be labelled substantive as it is a decision which excludes certain aliens from a right to permanent residency; however, it may also be procedural because it has the effect of significantly delaying a hearing. ${ }^{172}$ Thus in many immigration cases, a given classification may be characterized as substantive or procedural and the way in which an alleged violation is categorized will affect its possibility for passing constitutional muster. As one author notes with respect to practice:

Lawyers for aliens understand that a procedural label greatly enhances the likelihood that a constitutional challenge to an immigration procedure will succeed. Government lawyers fight for a substantive label to bring a case squarely under the plenary power doctrine, thereby taking full advantage of the political branches' immunity from constitutional challenges. ${ }^{173}$

The general approach of US courts in this area of the law has drawn much scholarly attention: 'The plenary power doctrine has eroded significantly in the past few decades and the evolution of procedural due process as an exception to plenary power has been a critical part of this trend'. ${ }^{174}$ Nevertheless, courts continue to review substantive claims with a rational basis test in many immigration cases, and the government is usually the victor when this is applied. Immigration law has been criticized as lacking a 'fully developed core of substantive constitutional rights of the type that has long existed by way of judicial review of substantive claims in

\footnotetext{
170 Whinnery, above note 168 , at 1092.

171 Azizi, 908 F.2d at 1136 (Cardamone, J. dissenting).

172 Motomura, above note 32 , at 1628 .

173 Ibid., at 1630.

174 Ibid., at 1631 .
} 
mainstream constitutional law'. ${ }^{175}$ The problem is best summarized by Motomura in an article analyzing the development of immigration laws under the plenary power doctrine:

Immigration law, as it has developed over the past one hundred years under the domination of the plenary power doctrine, represents an aberrational form of the typical relationship between statutory interpretation and constitutional law. The aberrant quality is attributable to the prolonged nature of the contradiction between the two sets of 'constitutional norms' in immigration law. The constitutional norms that the courts use when they directly decide constitutional issues in immigration cases are not the same constitutional norms that inform interpretation of immigration statutes. To serve the latter function, many courts have relied on ... 'phantom constitutional norms' which are not indigenous to immigration law but come from mainstream public law instead. The result has been to undermine the plenary power doctrine through statutory interpretation. ${ }^{170}$

\section{Conclusion}

Case law, treaties, legislative intent and the basic principles regarding family unification give credence to the family as an essential institution deeply rooted in the moral fibre of society and indicate a clear concern for both its preservation and promotion. Despite the lack of a unified approach to a right to family unity, similarities in interpretation in both the US and Europe reveal its nature as a right based in privacy and concerned with the freedom to develop and maintain close personal relationships that fall within a particular legal framework. Similarities also reveal that the right to lead a 'normal' family life requires non- (or at least minimal) interference by the State. It is with this latter requirement that a problem begins: As this article has shown, the conflict between State and individual interests pervades all family immigration issues. Although it is not overt, the question underlying most cases is where the line must be drawn between these competing interests.

The conflict is best seen in the application of the plenary power and State sovereignty doctrines simultaneously with the recognition of a basic right to family unity. This results in a tension in the law which is in critical need of resolution. In effect, the doctrines constitute a burden on the full exercise of the right to family unity in immigration matters. That the same right is treated differently outside the immigration sphere is increasingly difficult to tolerate in the face of a growing need for family reunification rights. Consider, for example, the difference between the treatment of the right to family unity by the United States Supreme

\footnotetext{
175 Ibid., at 1698.

176 Motomura, H., 'Immigration Law After a Century of Plenary Power: Phantom Constitutional Norms and Statutory Interpretation', 100 Yale Law Joumal 545, 549 (1990).
} 
Court in $M o o r e^{177}$ and the family immigration cases. In the latter, the 'sanctity of the family', with all its historical and traditional roots, as well as the due process aspects of the basic right to family unity, is diminished by the plenary power doctrine. Similarly, in family immigration cases under article $8 \mathrm{ECHR}$, an interference with the basic right to family unity is characterized as one which prevents enjoyment of that right elsewhere, as opposed to an outright limitation which would follow from an interference with any other basic right.

Notions such as procedural due process and positive obligations play an important role in family immigration cases by getting around the shortcomings of the older doctrines and by adding flexibility to the law. However, as these notions continue to be applied, the older doctrines need to be re-evaluated and adjusted to meet current realities. ${ }^{178}$ As the case law shows, the procedural due process and positive obligation analysis also have their drawbacks. The substantive-procedural distinction in US case law tends to be ambiguous, particularly where the plenary power doctrine is relevant. The different results in the Manwani and Azizi cases reveals a varying interpretation of the reach of the same constitutional rights, indicating the need to reconcile the power to remove matters from judicial review with the increasing recognition that families have a due process right to unification.

Problems with the positive obligation approach arise in establishing its scope. The point at which a State is obligated to act affirmatively to protect the right to family unity is unclear. Moreover, the interpretation of this notion also has a potential for ambiguity. The partly dissenting opinion of Judge Matscher in the Marckx case is illustrative of this potential where he notes that the positive obligation notion of article 8 'is limited to what is necessary for the creation and development of family life according to the ideas which contemporary European societics have of this concept'. ${ }^{179}$ Such standards leave much in the hands of individual judicial opinion.

Another concept in need of re-working, or perhaps even elimination, is the 'elsewhere approach'. Because its effect can pose extreme hardship by requiring an individual to leave his or her country of origin, or a country where he or she is well-established, it has been criticized as 'incompatible with effective human rights protection'. ${ }^{180}$ There are also numerous additional problems. Whether it is reasonable to expect a

\footnotetext{
177 Moore, 431 US 494.

178 Motomura eleganty suggests this point with regard to procedural due process and the plenary power doctrine: 'By hearing constitutional claims based on procedural due process, courts have basically created an exception to the plenary power doctrine, and this exception has now grown to the point that the necessity has arisen to rethink the rule.' Motomura, above note 32, at 1628.

It) Marck, above note 24 , at 57 .

18*) Cretic, above note 2, at 655; see also, Storey, above note 4, at 337.
} 
family to move to another country is extremely difficult to resolve and clearly subject to varying judicial opinion. Thus far, application of the test has burdened the European Court by giving it an extra role as a 'regulator of migration of couples from a State with deterrent immigration policies to a State where these policies are not so stringent'. ${ }^{181}$ Yet another difficulty is how to proceed when all States employ the test. Where do you send a family when all States involved find interests are best served by moving them elsewhere? Finally, pursuant to the European procedure for determining whether there has been an interference with the right to family unity, the 'elsewhere test' is an extra balancing test. The balancing of interests involved in determining whether a given interference is justified is sufficient; requiring a second balancing test places an undue burden on those seeking to exercise their right to family unity.

The 'elsewhere' approach concerns an issue fundamental to the right to family unity under both US and European law; it has further implications for the basic right to marry, namely, how effectively to protect the rights of couples of different nationalities. As one author suggests, the only practical solution is to allow these couples to exercise their right to family unity in both States within the confines of article $8(2)$ of the Convention or similar domestic provisions. ${ }^{182}$ To avoid outright country-choosing, consideration of an individual's connections to a State should remain relevant. Connections are also important for humanitarian reasons; forcing a person to leave a country in which he or she has spent most of their life and return to a country to in which there are no real or substantial ties is an extremely severe punishment that may not only interfere with, but also destroy family life.

In all family immigration cases the actual family situation should be the ultimate determining factor if the right to family life is to be protected and maintained. Whether there is a family life and whether it will be burdened or destroyed by a separation are issues to be dealt with at the outset, in view of the consequences for both the individual and the family. Thereafter, or perhaps even simultaneously, connections must also be considered as these play an essential role in establishing and defining the broader context of family life within a given culture.

With the recent changes in immigration patterns and the growing numbers of immigrants worldwide, family immigration cases are likely to increase. As this occurs, care must be taken to avoid any greater interference with the right to family unity than necessary. The conflict of interests and other problems inherent in the exercise of the right cannot be eliminated overnight. However, much can be done by way of reevaluating some older procedures and by developing clearer standards

181 Cvetic, above note 2 at 649 .

I82 Ibid., at 650. 
and definitions. Among other things, it is imperative that a closer look be taken at the role of the plenary power and State sovereignty doctrines in cases where families have been or are in danger of being separated. These doctrines are not likely to be abandoned in the near future as, among other things, they are essential to the preservation of State autonomy. However, the role assigned to them must be adjusted to accommodate the right to family unity. Where the right has been (or is in danger of being) violated, the role played by these doctrines must be minimized. Due process and positive obligations must be given precedence over deference to State sovereignty and plenary power. Furthermore, the value of maintaining the 'elsewhere approach' as a means of determining whether or not there has been an interference with the right to family unity in the European cases must be appraised in light of its many complications. As some recent case law has demonstrated, this approach is becoming obsolete because of the increasing recognition of the importance of the family in society. It is the family that is guaranteed protection, and we must not lose sight of the fact that the focal point for determining if there has been a violation of the right must be the family, and not the individual.

Family immigration cases today have taken on new dimensions, and the current legal framework for addressing these matters is in transition. The more recent emphasis on due process rights instead of plenary power and on positive obligations instead of sovereignty or the 'elsewhere approach', together with the recent second generation migrant cases in Europe, all indicate a liberal trend in the law which should be encouraged and broadened in order to preserve the full exercise of the right to family unity, and to maintain a humanistic quality in this area of the law. 